\title{
Landskampen Sverige-Danmark \\ - framväxten av en svensk fotbollsnationalism
}

\section{Af Torbjörn Andersson}

\section{Inledning}

Denna artikel ska belysa hur en svensk fotbollsnationalism gradvis växte fram från och med 1910-talet. ${ }^{1}$ Nyckeln i denna var den landskampstradition i form av matchen Sverige-Danmark, som tog sin början 1913. Det var denna match som blev den svenska idrottskalenderns årliga höjdpunkt; det var här som den idrottsliga svenskheten både formades, hyllades och ifrågasattes. Under mellankrigstiden hade en fast ritual etablerats runt landskampen i Sverige. Den svenska flaggan fanns på plats, nationalsången sjöngs och ett organiserat hejande förekom på arenan. Därmed hade en folklig nationalism skapats runt fotbollen, en nationalism som stod i klar kontrast till överklassens så kallade punschpatriotism som florerade i sekelskiftets Sverige.

Intressant är att landslagsfotbollen inte skapades utan vidare. Från start var fotbollen lokalt och regionalt inriktad, varför det nystartade fotbollslandslaget genast drogs in i regionala konflikter. Faktum är att lanserandet av landslaget utgjorde en smärtsam process, som innefattade flera konflikter med framförallt Stockholm och Göteborg i förgrunden. För landslagets vidkommande blev den grundläggande frågan huruvida det verkligen fungerade att blanda spelare från Stockholm och Göteborg med varandra. Senare kom också problemet med den skånska representationen in i bilden. Till detta ska läggas den parallella strid som fördes om var landskamperna skulle förläggas: i Stockholm, Göteborg eller kanske i Skåne?

Tydligt är att landslagstanken kan ses som en sorts konstruktion. För många människor tedde det sig långtifrån naturligt att betrakta landslaget utan lokalpatriotiskt färgade glasögon. Med denna tidiga utveckling i åtanke är det desto mer anmärkningsvärt att landslagstanken senare blev så stark i Sverige. Låt oss nu se efter hur det svenska landslaget sakta men säkert växte fram som en nationell symbol av dignitet.

Etnologen Orvar Löfgren har summerat läget i sekelskiftets Sverige med att det nationella var en konfliktarena mer än ett förenande fokus. Som exempel kan nämnas att socialdemokraterna i sin roll som både internationalister och modernister stod utanför de konservativa nationalistiska strömningarna. ${ }^{2}$ Överhuvudtaget påpekades ofta att svenskarna hade en föga utvecklad fosterlandskärlek. För kulturpersonligheter som Verner von Heidenstam, Gustav Sundbärg och Carl G. Laurin, som alla författade skrifter om det svenska folklynnet, framstod förhållandena som högst beklagansvärda. I de frekventa analyserna av den svenska nationalkaraktären tedde sig jämförelser med Danmark naturliga. Och föga konstigt var detta. Som etnolo- 


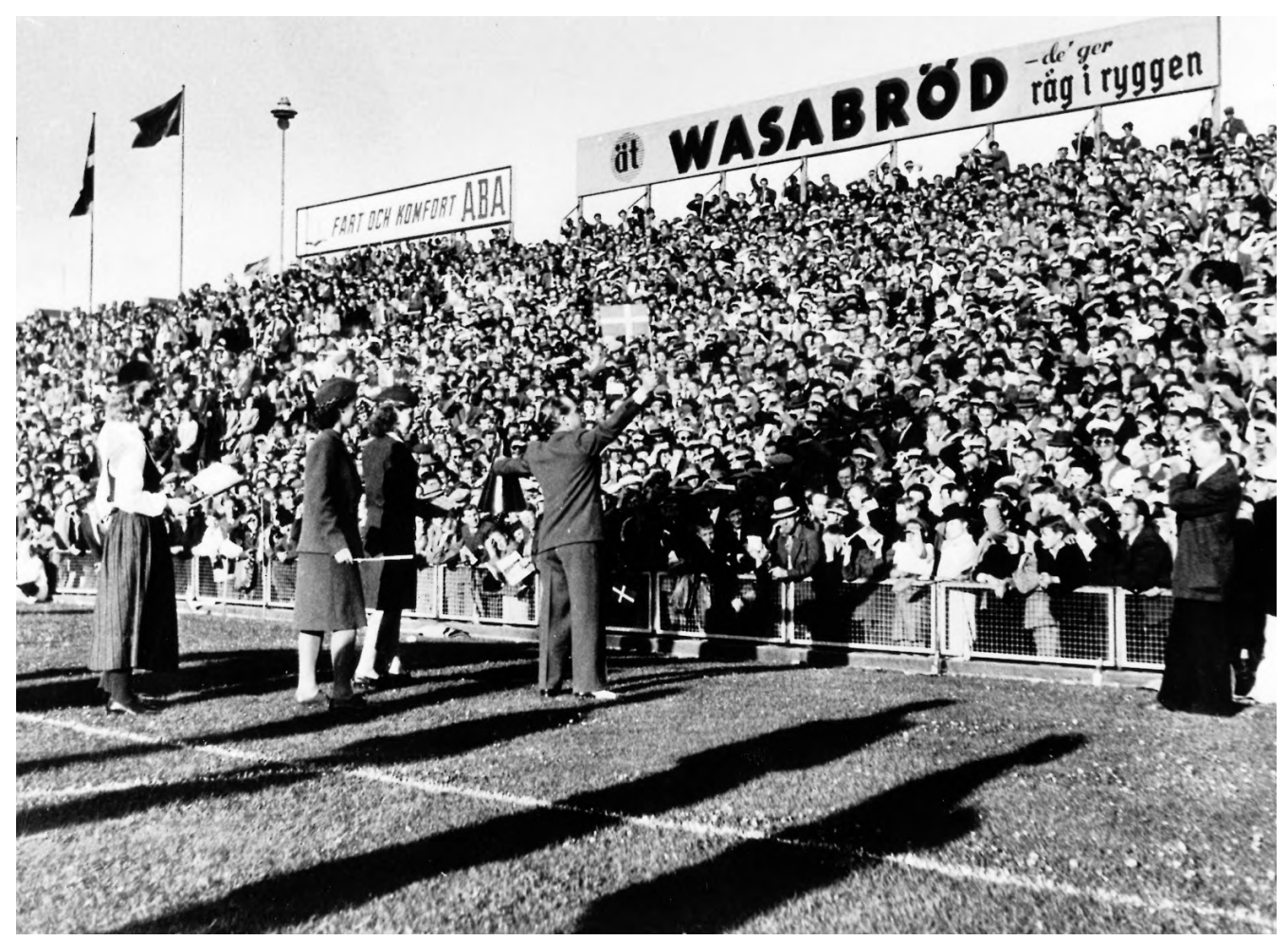

Bilden föreställer en hejaklacksledare på Råsunda i Stockholm.

gen Anders Linde-Laursen påpekat, med hänvisning till 1900-talets ständiga jämförelser mellan svenskt och danskt, fordras ett någorlunda jämbördigt jämförelsematerial för att man ska kunna uttala sig om en nationell stereotyp. ${ }^{3}$

Sålunda kom man också inom fotbollen - såväl inom landslags- som klubbfotbollen - att idogt konfrontera svenskt mot danskt. Snart skulle det komma att visa sig att de årliga landskamperna mot Danmark utgjorde den perfekta gjutform, där den svenska landslagstanken kunde formas och erhålla substans. Landskampen förvandlades till en tradition nästan från start 1913; danskarna erhöll snart epitetet »arvfienden« och en kombination av folkliga och mer officiella ritualer gav tillställningen en distinkt färg och särprägel, som höjde den högt över alla andra inhemska fotbollsmatcher. Trots detta tog det sin tid innan den svenska landslagsfotbollen blev till en riktigt levande tradition.

\section{Landskampstraditionens start}

Sveriges första landskamper gick av stapeln i Göteborg 1908 mot Norge och Englands amatörlandslag. Matcherna, som utgjorde ett led i förberedelserna inför OSturneringen i London samma år, väckte endast begränsat intresse i pressen och publiksiffrorna på ett par tusen personer imponerade inte. Upplägget runt landskamperna var i princip som kring vilka andra matcher som helst. Några ceremoniella inslag tycks inte ha förekommit; däremot hade beslutats att landslagets dräkt skulle vara blå 
och gul. Vid bägge tillfällena hade laget komponerats med spelare från olika städer, vilket inte hindrade att laguttagningarna föregåtts av debatter huruvida inte rena göteborgslag borde formerats.

Nya regionala åsiktsmotsättningar följde på landslagets misslyckade OS-turnering i Stockholm 1912. Inte heller här hade publikintresset för landslaget imponerat. Däremot började landslagsfotbollen vid detta tillfälle att ritualiseras då kronprinsen närvarat på många matcher och gått runt och hälsat och samspråkat med de olika ländernas spelare.

Ett tidigt mål för Sverige var att få till stånd landskamper mot den skandinaviska fotbollsstormakten Danmark. Trots påstötningar under flera års tid visade danskarna inget intresse, bland annat därför att svenskarna räknades som alltför dåliga. 1913 kom den efterlängtade matchen emellertid äntligen till stånd. Med denna landskamp skulle snart också det folkliga intresset vakna till liv, varigenom en tradition skapades som förband de övre klassernas ceremoniella nationalism med olika folkligt förankrade uttrycksformer. På så vis fick danmarksmatcherna sin givna betydelse för nationalmedvetandets tillväxt. Den bredare nationella samling som första världskriget resulterade $\mathrm{i}$ hade säkert sin del i att landskampen hade en sådan verkan på sinnena. Tilläggas kan att matcherna mot exempelvis Norge inte alls väckte samma intresse, främst beroende på att Norge utgjorde för svagt motstånd.

Premiärlandskampen mot Danmark utspelades i Köpenhamn på våren 1913 och slutresultatet, 8-0 till danskarna, väckte bestörtning på sina håll. Mest intressant är dock att finna den enorma uppmärksamhet matchen ägnades i pressen. Sporttidningen Nordiskt Idrottslif skrev exempelvis avsevärt mer om denna kamp än om tidigare landskamper, OS-matcherna inkluderade. Här framkommer tydligt vilken central roll idrotts- och dagstidningarna hade i den process som förvandlade landskamperna till nationella angelägenheter. Utan massmedia hade landskampen mot Danmark aldrig kunnat rotfästas så fast i människors medvetande. Det bör dock tilläggas att just denna match hade en publik potential. I Sverige var kamperna efterlängtade. Bland de 8.000 åskådarna fanns en hel del svenskar, som rest till Köpenhamn från Skåne, Göteborg och Stockholm. Från början etablerades alltså en resekultur, vilken senare kom att växa betydligt i omfång.

En förklaring som gavs till förlusten var att lag sammansatta från olika städer inte höll måttet, delvis beroende på att kamratskapet inte blev lika bra som i klubblagen. Därför prövades redan samma år en annan modell när ett ograverat IFK Göteborg fick representera Sverige på bortaplan mot Norge. Initiativet hade tillkommit efter nästa brakförlust mot Danmark på hösten 1913 i Stockholm. Nederlaget på 10-0 fick den svenska fotbollsvärlden att klyvas mitt itu. I Göteborg ledde upprördheten till att man försökte avsätta Svenska Fotbollförbundets ledning. Ett offentligt diskussionsmöte utlystes och dit kom över tusen personer! Mötet utmynnade i ett krav att Göteborg och Stockholm, var för sig, fick omhänderta uttagningen av ett lag, varefter det bästa skulle representera Sverige. Nordiskt Idrottslif betecknade mötet som en revolution inom den svenska fotbollen bottnande i avundsjukan mellan Göteborgs och Stockholms fotbollskretsar. Omstörtningsförsöket misslyckades dock, men kuppen hade varit tillräckligt välregisserad för att permanenta konflikten mellan Göteborg och huvudstaden. Hädanefter följde ändlösa debatter om hur landslaget borde sammansättas. 
Efter en ny förlust 1915 lade Idrottsbladets inflytelserike Torsten Tegnér fram sin syn på varför danskarna befann sig på en högre nivå. Svaret var »att $i$ vårt grannland fotbollslagen vanligtvis rekryteras från andra samhällsklasser än här $i$ landet« - ett uttalande som hänsyftade på att tre akademiker, två bankmän och två artillerilöjtnanter fanns i elvan. ${ }^{4}$ Tegnér resonerade vidare:

»Det är helt naturligt, ja självklart, att män, som hela sin barndom och ungdom igenom metodiskt skolats $i$ fysiskt och intellektuellt avseende och sluppit umbäranden och hårt förvärvsarbete, skola ha de bästa chanserna i de idrottsgrenar, där det kommer an såväl på kraft och vighet som på disciplin, beräkning och list. $\ll^{5}$

Tegnérs uppfattning låg i linje med tidens allmänna strömningar som gjorde gällande att Danmark var det gamla kulturlandet, medan Sverige alltjämt var ett primitivt land, om än på kraftig frammarsch. Följaktligen betonades ofta inom fotbollen att läromästaren Danmark innehade fotbollskultur till skillnad mot Sverige. Sett ur ett sådant perspektiv var inte den svenska fotbollens tidigare demokratisering en odelat positiv utveckling. Inom kort började dock även klasstrukturen inom dansk fotboll att förändras. Typiskt nog utgjorde klassbreddningen för Tegnér ett säkert tecken på deklassering i vilken förklaringen till den danska landslagsfotbollens hastiga tillbakagång stod att finna. 1920 såg han med nostalgi tillbaka på den gamla goda tidens danska spelare: »Vi sakna dem, och vi beklaga som en oersättlig förlust för Nordens idrott att deras efterträdare äro av lägre klass, av arbetarklassen. $\ll^{6}$

För flertalet yttre betraktare var skillna- den mellan svensk och dansk fotbollskultur slående runt första världskriget. Sverige led av ett mindervärdighetskomplex, vilket bottnade i den danska fotbollens högre sociala status. Dansk fotboll förknippades med en för svenskt vidkommande ouppnåelig förfining, som tog sig uttryck i ett intelligent spel. Kontrasten länderna emellan kom att accentueras ytterligare av supportrarnas uppförande. Svenska fotbollsanhängare framstod inte så sällan som lågt stående varelser och skälet till detta var det onyktra beteende som uppvisades av de supportrar som tagit sig till Köpenhamn, ofta med de så kallade extratågen, vilka erbjöd transport till rabatterade priser. Ett första bottennapp utgjorde 1916 års göteborgska extratåg. Det uppmärksammades då det fraktat en hop berusade ynglingar, vilka satte »en fläck $p a ̊$ hela den svenska idrottsrörelsen $\ll^{7}$ Om stämningen i Köpenhamn året efter skrev Idrottsbladet: "Aldrig torde Köpenhamn ha varit så fullt av fulla svenskar som den 3 juni $1917 \ll .8$

Även därefter kom resandet till och därmed dryckenskapen i den danska huvudstaden att bli en given del i landskampstraditionen. Också till kamperna i Stockholm ordnades extratåg från svenska städer, liksom från Danmark. Mycket av charmen och styrkan i landskampen kom just att ligga $\mathrm{i}$ att högt och lågt blandades då strikta ritualer och folkliga uttryck inbegreps i samma skådespel; en danmarksmatch bevittnades inte bara av hovet utan också av burdusa åskådareskaror, som tog hjälp av alltifrån basuner och automobiltutor till harskramlor och visselpipor för att skapa rätt stämning. På så vis innefattade danmarkskamperna nationalistiska uttrycksformer som passade olika smakriktningar. 


\section{Flaggan och nationalsången}

Genom de frekventa fotbollslandskamperna erhöll det Michael Billig kallat för en banal nationalism ett stadigare fotfäste. Nationalismen fick ett alldagligt utseende då den gestaltades och ritualiserades genom spelarnas landslagsdräkt, nationalsången och nationsflaggan. Den banala nationalismen befästes ytterligare genom tidningarnas ständiga skriverier om just det svenska landslaget och svenska spelare. ${ }^{9}$ På så vis bidrog fotbollssporten till att förankra nationalismen djupare i samhället. Det flaggande som runt sekelskiftet allmänt förknippades med en överklassnobbism blev på idrottsplatserna snarast ett tecken på en mer djupgående och common sense-betonad nationell gemenskap. Viktigt i sammanhanget var att landskampsfotbollen tidigt blev ett nationellt uttryck som också många inom socialdemokratin kunde ställa sig bakom. Fotbollsspelet uppfattades som demokratiskt och modernt. Per Albin Hansson, den senare socialdemokratiske landsfadern, yttrade redan 1904 att den socialdemokratiska ungdomen, till skillnad från överklassen, hade en äkta fosterlandskänsla, varför det inte förvånar att han med sådan glädje välkomnade landslagets fotbollsframgångar.

1915 års danmarksmatch i Stockholm markerade ett avgörande genombrott för evenemanget. 14.000 personer hade då fyllt Stadion (att jämföra med 7.000 på premiären 1913), däribland kungafamiljen, och det rapporterades att massor av svenska flaggor synts på arenan. Landskampens allt starkare symbolbetydelse manifesterades två år senare när Sveriges kronprins fanns på plats i Köpenhamn, vilket alla blev varse då han under halvtidspausen gick runt tillsammans med den danske kungen och i demokratisk anda hälsade på spelarna. Även på bortamark rapporterades att de blågula färgerna nu observerats överallt bland publiken.

På det hela taget började flaggan att förbindas med idrotten. 1916 bildades $B e$ styrelsen för Svenska flaggans dag och den organisationen såg till att idrottsmän ställde upp på det årliga evenemang man anordnade. Visserligen har etnologen NilsArvid Bringéus påpekat att firandet av Svenska flaggans dag växte fram genom centraldirigering och propaganda och heller aldrig utvecklades till en riktig folkfest. ${ }^{10}$ Inte desto mindre kom fotbollsfolket att troget medverka i det årliga firandet av Svenska flaggans dag runtom i landet den 6:e juni. Att just den brett förankrade fotbollssporten närvarade var viktigt, eftersom tanken med högtidsdagen var att skilda partier och politiska åskådningar enades kring fosterlandets symbol.

Till saken hör att den svenska flaggan ursprungligen varit ett militärt samlingstecken, som först på 1870-talet började nyttjas i civila och privata sammanhang. Det var ståndspersoner som banade väg för seden att hissa fanan. När samma fana från och med 1890-talet kom att förknippas med försvarsrörelsen misskrediterades den inom arbetarrörelsen; fanan framstod som en grundmurad konservativ symbol. Utan att ta till överord kan påstås att sporten blev det område, där fanan först fick en folklig framtoning. Landskampspublikens spontana flaggviftande gav en ovärderlig hjälp åt det populariseringsarbete Bestyrelsen för Svenska flaggans dag givit sig i kast med.

Även nationalsången $\gg \mathrm{Du}$ gamla, du fria « introducerades efterhand på landskamperna. Det tycks som om den först spelades i Köpenhamn 1918 då den ingick i den repertoar av populära melodier som spelades före avspark. Nordiskt Idrottslifs 
referent konstaterade missbelåtet att stycket föreföll obekant, inte bara för den danska publiken utan även för en del svenskar. Detta förvånar nu inte. Nationalsånger utgjorde i allmänhet ett ganska nytt fenomen och i Sverige hade man till råga på allt bytt nationalsång en gång. Ända in på 1890-talet var det »Kungssången « som gällde, en sång som med förkärlek sjöngs inom fotbollens snobbiga gentlemannamiljöer under seklets början. Liksom fallet var med den svenska flaggan hade nationalsången, alltså »Du gamla, du fria«, ingen förankring inom arbetarklassens led. Överhuvudtaget förknippades hela den manliga sångkörstraditionen med en konservativ och ursprungligen studentförankrad fosterländskhet.

$\mathrm{Nu}$ skulle den svenska fotbollspublikens sångarinsats komma att förbättras. Under mellankrigstiden fick landskampsritualen sin givna form. Hur denna såg ut framkommer i Per-Axel Branners spelfilm, Hans livs match (1932), vilken innehåller en lång filmsekvens från 1931 års danmarkskamp i Stockholm. Stadion är då prydd med en mängd svenska flaggor. Danmarks lag springer först in på plan och posterar sig i givakt här och där på ena planhalvan. Den danska nationalsången framförs av en musikorkester ackompanjerad av stående och sjungande åskådare, många med blottade huvuden. Därefter kommer svenskarna in på arenan till ett stort jubel, varefter ritualen upprepas med än större publik emfas och alltmedan allsången ljuder hissas ännu en svensk fana upp i skyn. Iscensättningen är i det stora hela precis densamma än idag.

\section{Nationstanken segrar}

Känslan för det nationella närdes av de sportsliga framgångarna. En direkt milstol- pe utgjorde Sveriges första seger någonsin mot Danmark 1916 (4-0). Vid denna match gjorde ännu ett nationellt samlande fenomen sin definitiva entré inom svensk idrott. Det var det organiserade hejandet. Dessa organiserade talkörer kan ledas tillbaka till den amerikanska studentidrotten under 1890-talets slut, men kom i Europa att utvecklas till att bli ett kännetecken för just svensk publikkultur. Fenomenets upprinnelse på svensk mark kan dateras till Stockholmsolympiaden 1912, där en amerikansk hejaklack stöttade sitt lands friidrottare. Impulserna från olympiaden gjorde att ett löst organiserat hejande snart förekom på en och annan match i Sverige.

Snart kom ett specifikt hejarop att skandera under fotbollslandskamper på Stadion, nämligen de rader som snart blev världens mest kända hejaramsa: »Heja grabbar, friskt humör! Det är det, som susen gör! Heja! Heja! HEJA! «. Ramsan var resultatet av en pristävlan som utlysts av stadionchefen Erik Bergvall inför landskampen mot Danmark i Stockholm 1916. Skådespelaren Axel Hultman hade författat de senare så klassiska raderna och han ledde själv publikens hejande - och utfallet blev Sveriges första landskampsseger någonsin mot Danmark.

Hejaklackarna utgör ett exempel på hur ett fenomen skapas uppifrån, i detta fall ur amerikansk studentmiljö och svensk medelklass, för att sedan spridas på massbasis bland åskådarna på ståplats. Här förelåg ett samspel mellan klasserna och generationerna, där ett ungdomligt och folkligt utspel uppmuntrades, men ändå hölls under strikt gentlemannamässiga och kontrollerade former. Att vad som helst inte kunde tänkas slå an hos folket framkom av att Bergvall själv kontaktade den konservative skalden och författaren, K.G. Ossiannilsson, med uppdraget att producera en slag- 


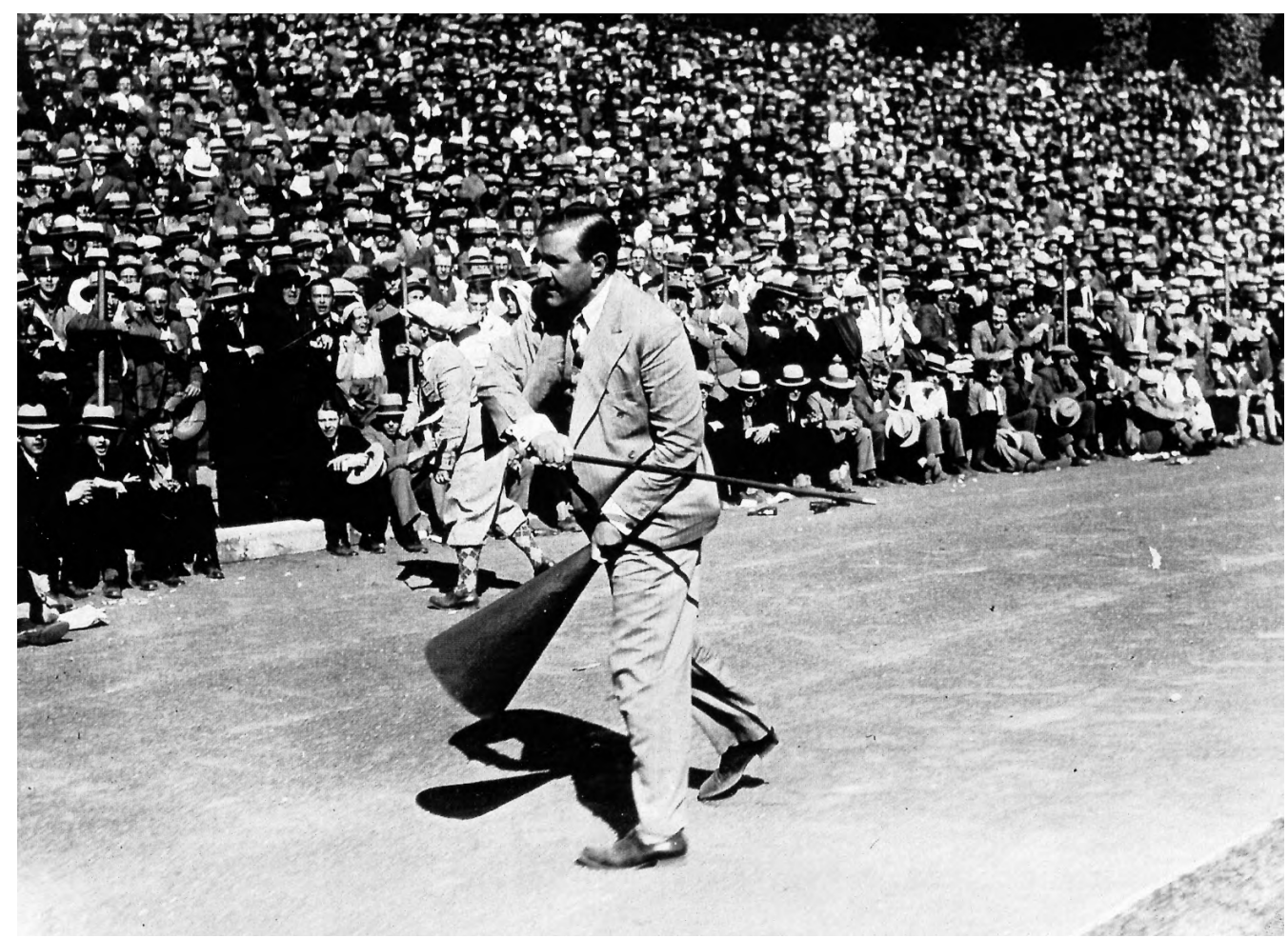

Bilden föreställer den svenske hejaklacksledaren, revyartisten, Ernst Rolf på Stockholms Stadion under mellankrigstiden.

kraftig ramsa. Till Ossiannilssons stora förtret dög inte vad han författat. Det var en alldeles för vacker och högstämd dikt som inte bedömdes ha någon framtid på fotbollsläktarna.

Tydligt var att landskampen mot Danmark fick en allt större prestige då svenskarna närmat sig läromästarnas standard. Då stora delar av den internationella fotbollen ödelagts av kriget kunde 1917 års match i Stockholm uppges gälla »vilken som för närvarande är Europas, för att icke säga världens främsta fotbollnation $\ll .{ }^{11}$ Det poängterades vilken enorm betydelse danmarksmatchen nu fått: »Utgången av en dylik match har ett kolossalt inflytande pà stämningen $i$ landet; icke blott inom de aktiva männens leder, utan även hos de $i$ allmänhet mera kallsinnade. $\ll^{12}$

Trots att den svenska fokuseringen på landskampsfotbollen hela tiden ökade, så förblev missämjan runt landslaget ett ledtema första världskriget igenom. Missnöjet över de regionala motsättningarna fick Aftontidningen att 1915 utbrista: »Låt oss äntligen en gång kunna möta upp mot Danmark med ett lag från Sverige, icke från Stockholm, Göteborg eller Malmö«. ${ }^{13}$ Två år senare ondgjorde sig Nordiskt Idrottslif över den rådande principen att Stockholm, Göteborg eller Skåne stod för landslaget. »För folk, som inte kan se tillräckligt $i$ stort, blir det icke Sverige som spelar utan blott en stad, ett landskap «. ${ }^{14}$ Som en följd av detta förvandlades ett 
svenskt nederlag gärna till ett nederlag för en viss landsända.

Den regionala rivaliteten tilltog 1918 när Göteborg för första gången fick arrangera en landskamp mot Danmark. Då piskades stämningen upp av Göteborgs Morgonpost som protesterade »mot att några stockholmare 'prackas på' den göteborgska elvan «. ${ }^{15}$ Tidningen bönfölls med resultatet att det svenska göteborgslandslaget förlorade. Den förklaring som gavs till nederlaget av den landslagsansvarige, Hugo Levin, kan tyckas märklig. Han menade att göteborgsspelarna - till skillnad från stockholmare - inte kunde gripas av någon verklig entusiasm inför uppgiften. Vidare framhölls att den bättre konditionen inte räckte till mot danskarna, som »stodo på en helt annan intellektuell nivå ${ }^{16}$

Till slut skulle dock den nationella tanken visa sig vara starkare än de regionala särintressena. Genombrottet skedde 1919 när ett göteborgslandslag uttagits till matchen mot Danmark i Stockholm. Strax dessförinnan hade ingen mindre än Svenska Fotbollförbundets sekreterare, Anton Johanson, på en landslagsbankett fällt det kontroversiella uttalandet, att göteborgarna inte voro några riktiga svenskar! Till förspelet inför kraftmätningen mot Danmark hörde också en intensiv göteborgsk tidningskampanj, vilken lett till att stockholmsspelarna avstått från att komma på tal för uttagning.

Frågan var nu hur huvudstadspubliken skulle reagera på den svenska göteborgskompositionen? En påtaglig oro låg i luften: »Göteborg mötte ej enbart Danmarkå Sveriges vägnar - det mötte ock delvis stockholmspatrioterna $\ll{ }^{17}$ Nordiskt Idrottslif ställde sina förhoppningar till att stadionpubliken trots allt skulle förstå att det var Sveriges och ej Göteborgs lag som representerade de blågula färgerna. Allt slu- tade lyckligt då segern hembärgades och åskådarnas attityd varit den rätta: »Publiken var välvilligt stämd och hälsade laget med en hjärtlig applåd vid inträdet på plan. Och det hejades på svenska laget. Ärligt och uppriktigt.« Det konstaterades att »Stockholm och hela det öfriga Sverige står $i$ en ofantligt stor tacksamhetsskuld till göteborgsspelarna just nu«. I Nordiskt Idrottslif hävdades att tiden nu blivit mogen för en nationell försoning, eftersom en regional balans uppkommit genom denna första viktoria mot läromästarna sedan 1916: »Och nu kan Stockholm och Göteborg ta varann $i$ hand. Båda ha de nu vunnit var sin stora seger över Danmark «.18

Härefter kom relationen mellan Stockholm och Göteborg att förbättras. Trots detta påstod fotbollsauktoriteten Carl »Ceve« Linde så sent som 1920 att spelarna från de skilda städerna inte kunde känna odelad sympati för varandra.

Otvivelaktigt hade danmarksmatchen vid denna tid fått en allt nationellare och folkligare karaktär. Publiksiffrorna på Sveriges hemmamatcher ökade. För perioden 1908-1914 låg publiksnittet på drygt 4.500 (16 matcher, varav en mot Danmark), medan det 1915-1920 stigit till över 12.600 (17 matcher, varav 6 mot Danmark). En annan siffra som belyser intresset är Idrottsbladets upplaga i samband med danmarksmatcherna. Ett nytt rekord sattes för 1916 års hemmalandskamp med 9.600 exemplar; samma match året efter ökade upplagan till 17.200 och på den vägen fortsatte det.

Sammanfattningsvis kan sägas att en klassövergripande och folklig nationalism kommit att känneteckna fotbollslandskamperna. Skillnaden var slående mot den punschpatriotism, som florerat inom sekelskiftets överklassmiljöer. Ett visst fog fanns för sportpressens belåtna utrop efter 


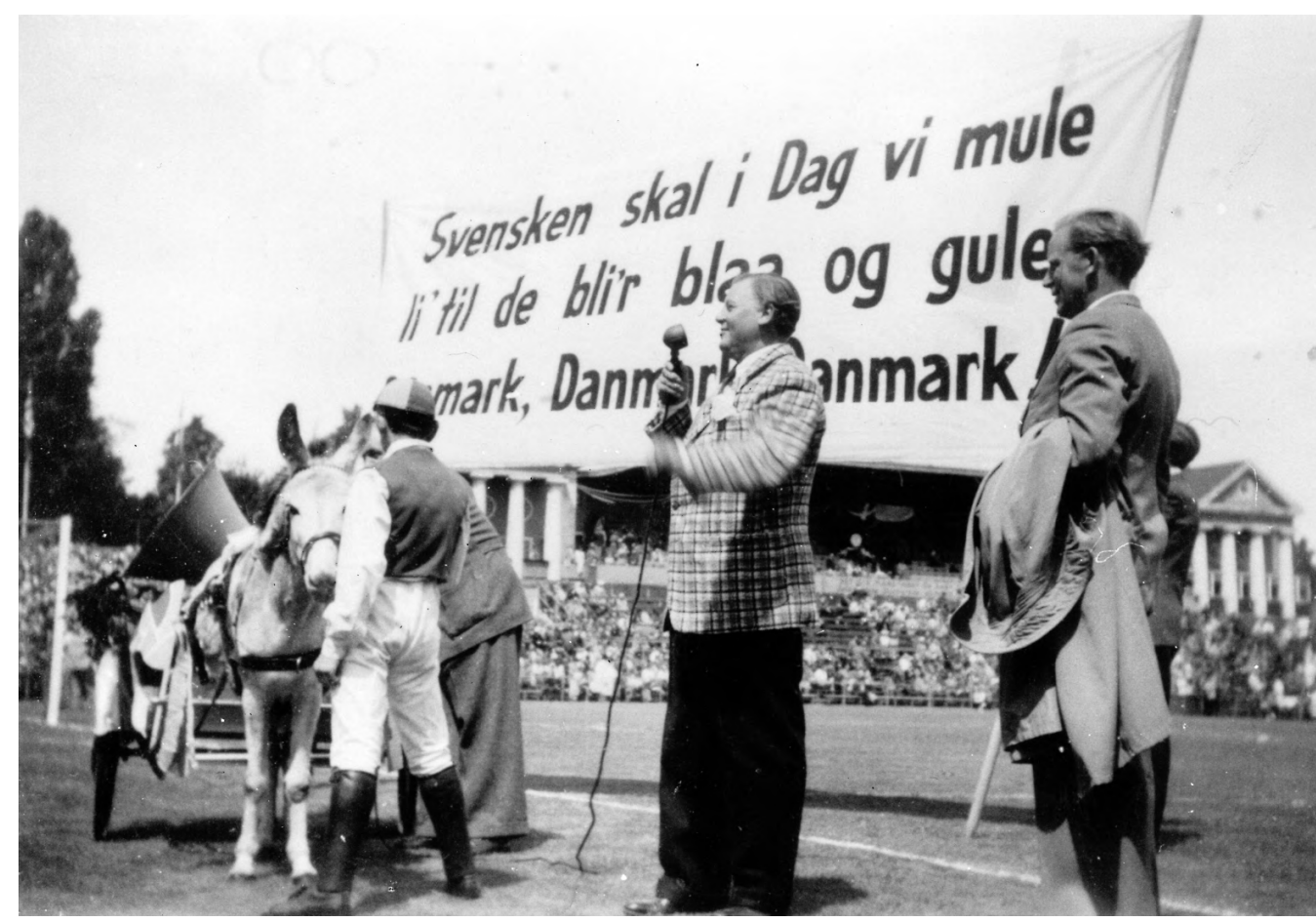

Bilden föreställer en dansk så kallad hurtigmalere $i$ Idratsparken $i$ Köpenhamn $i$ en landskamp mot Sverige.

en landskampsseger 1920, att »Den svenska olympiaelvan är väl det enda, som kan åstadkomma nationell samling $i$ dessa valtider $\ll .{ }^{19}$

\section{Mellankrigstiden}

Under mellankrigstiden höll landskampen mot Danmark ställningen som årets höjdpunkt. I Idrottsbladet hyllades 1922 års seger med orden: »När Sverige spelar landskamp, så är det Sverige som spelar. Inte Skåne. Eller Göteborg. Eller Hälsingborg. Det blev man klok på i Köpenhamn $\ll{ }^{20}$ Typiskt nog valde emellertid en göteborgstidning att $\mathrm{i}$ gammal huvudstadsfientlig anda precisera att segern hemförts »av fem skåningar, fem göteborgare och en stockholmare ${ }^{21}$
Tydligt var att konflikterna mellan spelare från olika landsändar efterhand försvann. Efter 1931 års seger över Danmark lyftes fram att spelarna plockats från sju olika klubbar och att kamratskap rått fastän flera personer inte kände varandra. Tidigare klagomål från huvudstaden, att göteborgsspelare inte gjorde sitt bästa i landslagssammanhang, kunde avskrivas. Några år därefter konstaterades att man även i Skåne insett att Danmark kunde besegras i Köpenhamn med ett svenskt lag och inte bara av en skånekombination. Lika viktigt var den goda stämning som efterhand uppstått mellan länderna. Efter 1929 års uppgörelse klargjorde Dagens Nyheter att »medan man $i$ Sydeuropa och på andra håll på kontinenten slåss och djävlas vid de stora fotbollmatcherna, bidraga dessa 
verkligen här uppe till att stärka vänskapen mellan nationerna ${ }^{22}$ En uträkning från 1936 visade att Sverige och Danmark var de två länder i världen som haft störst fotbollsutbyte med varandra, sammanlagt över tusen klubb- och landslagsmatcher. ${ }^{23}$

En intressant aspekt med mellankrigstidens landslagsfotboll är att den ansågs belysa nationalkaraktären. De tankar Gustav Sundbärg lagt fram redan 1911 i boken Det svenska folklynnet var ännu levande. Landslaget kunde inte (med framgång) anamma vilken spelstil som helst. I Idrottsbladet företogs 1921 en utläggning om långpassningsspelets olämplighet med svenskhetens innersta drag:

»Tvärtom är svensken genom sin noggrannhet, sin kallblodighet, sitt lugn, sin brist på naturlig snabbhet, sin genom gymnastik och allsköns vintersport välbalanserade kropp bättre lämpad för kortpassningsspelet $\ll .{ }^{24}$

Då den svenska fotbollen ännu inte skördat några större framgångar kunde man undra $\mathrm{i}$ vilken utsträckning landets nationalkaraktär verkligen lämpade sig för fotbollsspelet. »Våra gossar kunna varken vinna på sin hurtiga, omedelbara naivitet - som norrmännen - eller på sitt kvickare och mer durkdrivna intellekt (som danskarne). De äro alltså både för mycket och för litet kultiverade «. ${ }^{25}$ Så sent som 1933 påstod Carl »Ceve« Linde att Danmark hade en stor konkurrensmässig fördel gentemot Sverige, därigenom att de alltjämt rekryterade flera spelare från studenternas och »hjärnarbetarnas « led. ${ }^{26}$ Trots att svenskarna sedan länge hävdade sig väl mot Danmark existerade ett efterhängset mindervärdighetskomplex.

Om man från svenskt håll beundrade den danska spelstilen, så var förhållandet annorlunda från dansk sida. Danskarna hade länge hävdat att Sverige överdrev hårdheten och nu hänvisades till John »Broarn « Perssons spelstil - en spelare som sällade sig till de hårdföra svenskar som gått till historien som »danskdödare«. »Ceve« Linde förklarade dock att »just den vikingafotboll, Broarn representerar, är svensk och det är den vi önska se... Han spelar hårt men juste« och representerade den karolinska andan. ${ }^{27}$ Det övergripande problemet för Sveriges del tycktes vara att man spelade för hårt enligt dansk måttstock, men alldeles för snällt i jämförelse med den kontinentala fotbollen. 1935 påstod journalisten och fotbollsdomaren Rudolf »R:et« Eklöw att svenskar som regel spelade med en överdriven humanitet, vilken tydde på att landets fotboll blivit förvekligad.

Sveriges svaga fotbollsinsatser på internationell nivå under 1930-talets andra hälft ledde till fortsatta grubblerier huruvida svenskar verkligen hade naturlig talang för fotboll. »De passa oss ej att improvisera och spela rent intuitivt - kanske därför att vi inte ha någon intuition «, löd »R:et « Eklöws omdöme. Han gav inte heller mycket hopp för framtiden: »Men nu är det ju en gång så, att vår ras passar bra mycket bättre för det enkelriktade och rätlinjiga än att ge sig $i$ kast med mer komplicerade uppgifter $\ll{ }^{28}$ Kort sagt skulle det svenska folkmaterialet kommit till sin rätt främst $i$ individuella idrottsgrenar och inte $i$ en sådan komplex gren som fotbollen.

\section{Andra världskriget}

1940-talet markerar en närmast total scenförändring för svensk landslagsfotboll. $\mathrm{Nu}$ fick Sverige fram ett starkt manskap, tveklöst ett av Europas och världens allra bästa. 


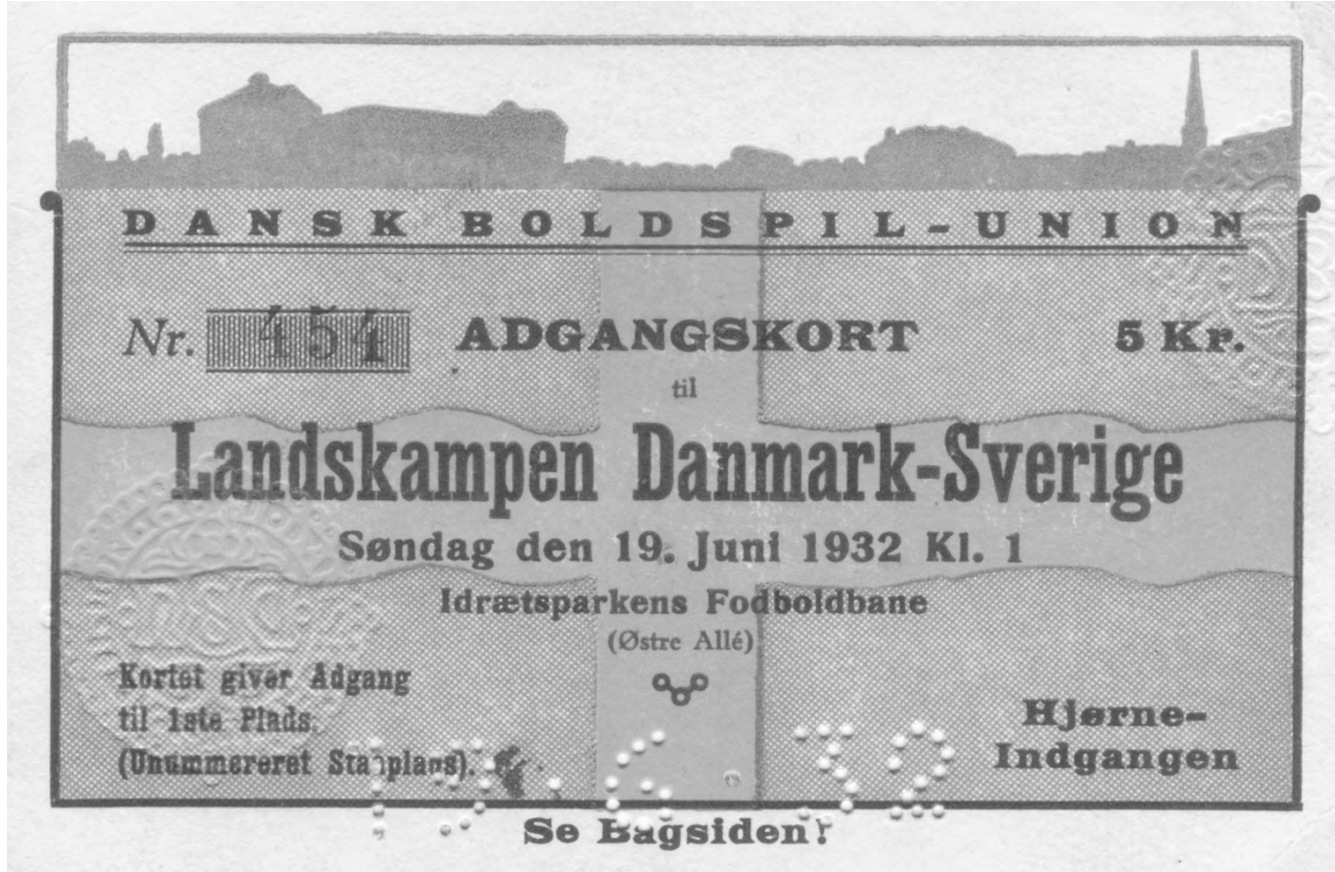

En matchbiljett från Danmark-Sverige i Köpenhamn 1932. Intressant är att den svenska flaggan avbildats på biljetten. Landskampen slutade 3-1 till Danmark.

Vid krigets ingång drogs Sverige dock alltjämt med tvivel, såtillvida att det svenska kynnet inte ansågs riktigt lämpat för fotbollen. Förhoppningen låg $\mathrm{i}$ att bollsinnet kunde övas upp, med då krävdes att landslaget konfronterades med utvecklande motstånd. Sådana opponenter fanns förstås i Skandinavien, i form av Danmark och Norge, men från dessa hördes fortsatta invändningar om att svenskarnas spel präglades av en överdriven hårdhet. Från svenskt håll gjordes tvärtemot gällande att ett kraftigt, manligt spel av engelsk modell var att föredra, medan $» N a ̊ g o n$ sorts form av frökenfotboll passar tydligen danskar och norrmän bäst «. ${ }^{29}$

Uppenbart var ändå att den något ansträngda stämningen mellan Sverige och Danmark lättades upp väsentligt under kriget. Den tidigare resultatorienteringen i matcherna övergavs. I bankettalen underströks gång efter annan den nordiska gemenskapens betydelse. Efter en svensk seger i Stockholm 1942 yttrade sålunda statsministern Per Albin Hansson:

»Jag skulle ha varit minst lika glad om det danska laget vunnit - detta inte sagt $a v$ ointresse för de egna eller brist $p a ̊$ nationalmedvetande. Men: det kändes som om det var två svenska lag som möttes. Vår samhörighet har blivit till den grad stark. $\ll^{30}$

Under krigsåren hade sympatin nationerna emellan en folklig grund. Det framkommer i ritualerna runt landskamperna, där köpenhamnspubliken under kriget och den tyska ockupationen sjöng den svenska nationalsången med en aldrig förr hörd kraft. 


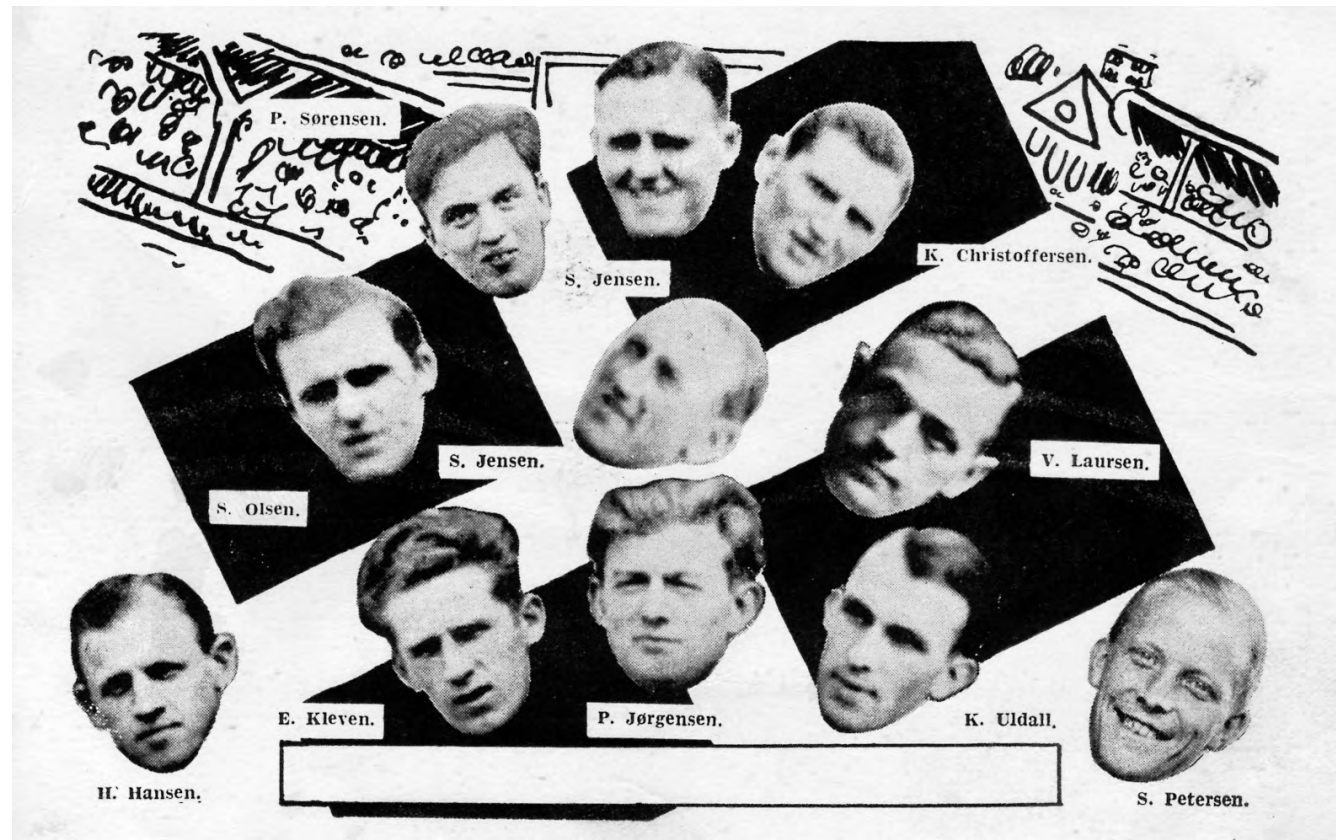

Ett vykort från samma match som biljetten, 19/6 1932 i Köpenhamn, med danska laget på. Det är ett reklamvykort från B.T., där man på baksidan uppmanas att skriva matchresultatet och skicka vykortet till någon. Portot är förbetalt av B.T.

Det rapporterades att mottagandet i Köpenhamn i oktober 1940 var det bästa ett svenskt lag fått utomlands på väldigt många år. De svenska åskådarna återgäldade samhörighetsgesten året efter genom att sjunga med $\mathrm{i}$ den danska nationalsången och frikostigare än vanligt applådera danskarnas spel.

Fotbollens allt starkare nationella betydelse underströks av kraven på att de stora landskamperna skulle sändas i radio. Kritik hade väckts mot att 1941 års danmarksmatch i Stockholm inte transmitterats till svenska folket. Senare under året gav Svenska Fotbollförbundet till sist upp sitt långlivade motstånd mot radiosända landskamper. Att frågan hade tyngd framgår av att regeringsrepresentanter kopplades in i de förhandlingar, vilka ledde till att 1941 års höstkamp mot Danmark i Köpen- hamn fick sändas. Därefter godtogs utan vidare debatter att de viktigaste fotbollslandskamperna transmitterades. Kursändringen framstår som en slutlig bekräftelse på att landslaget upphöjts till en nationell angelägenhet av rang.

För den svenska fotbollen började guldåldern under andra världskriget. Spelet hade utan några allvarligare störningar fortgått kriget igenom, medan andra länder omöjligen kunnat upprätthålla sin fotbollsstandard under förödelsen. I Sverige hade spelet hög prioritet. Därför kom också det danska landslaget till Stockholm strax efter krigsslutet i vad som blev den första officiella landskampen i världen efter fredsinträdet. Evenemanget iscensattes som en hyllning till det danska folket och en återföreningsfest för den nordiska idrotten. I förväg uppmanades publiken att lära sig 
texten till den danska nationalsången, vilket ytterligare lämpade sig i och med att matchen skulle direktsändas i radio i bägge länderna. Resultatet blev att ramen kring begivenheten slog an vida mer än själva matchen (som Sverige vann med 2-1). Veckan efter fortsatte hyllningsscenerna för Danmark då lagen möttes i Köpenhamn. En tredje landskamp kom till stånd under året och vid detta tillfälle hedrade sig stockholmspubliken med att på hejaklacksledarens kommando kraftfullt heja på danskarna. Från svensk sida betonades att de tre danmarksmatcherna 1945 skulle ses som ett led i fotbollens återuppbyggnad i Norden, varför man kontaktade FIFA med önskemålet att de inte skulle betraktas som officiella landskamper. Med andra ord underströks att matchresultatet (tre svenska segrar) hade en underordnad betydelse.

\section{Efterkrigstiden}

Under efterkrigstiden skördade svensk landslagsfotboll stora framgångar. Intressant nog försämrades därigenom relationen med de nordiska grannländerna. De stora förbrödringsscenerna runt krigsåren tynade hastigt bort och ersattes av en skarp rivalitet. »Ceve« Linde hävdade 1947 att grannländernas folk, utanför de officiella banketterna, visade upp ett kollektivt anlete »som är hånfullt, hatfyllt och hotfullt avundsjukt och grinigt gentemot allt svenskt «. ${ }^{31} \mathrm{Nu}$ ansågs kriget vara den främsta orsaken till motviljan. Sveriges hållning under krigsåren ingav inte full respekt och dessutom skulle landets rikedom ha stuckit i ögonen.

Relationen mellan Sverige och Danmark sjönk till en bottennivå i efterdyningarna av 1948 års olympiad i London. För Sverige var turneringen - som slutade med OSguld - den största framgången någonsin.
Till händelseförloppet hörde att just Danmark besegrats i semifinalen. Den matchen fick ett hett efterspel för att danskarna beskyllde Sverige - läs Bertil Nordahl - för ett hänsynslöst spel.

Anklagelsen passade in med den rådande synen om skilda nationaltyper och fotbollssystem. Danmark betraktade sig som gentlemannamoralens väktare i egenskap av att vara »de sista amatörerna « och fördömde utifrån denna position Sveriges busaktighet och alltför professionella fotbollskultur, allt uttryckt i en sorts jesuitisk moral präglad av viljan att vinna till varje pris. Sverige å sin sida avfärdade danskarna som dåliga förlorare, vilka tappat omdömesförmågan i sitt envetna försvar av amatörismen.

På det hela taget var svenskarnas nationella självförtroende nu av sådan art att man utan svårigheter kunde vifta bort alla beskyllningar som riktades från danskt håll. Att det i Danmark rentav fanns de som förordade att avbryta landslagsförbindelserna med Sverige spelade ingen roll. »Ceve« Linde konstaterade att dansk fotboll var långt mindre demokratiskt uppbyggd än svensk och Torsten Tegnér fyllde i med att danskarnas syn på amatörfrågan låg kvar på 1800-talsnivå.

Den traditionsenliga landskampen mellan Sverige och Danmark kom trots allt till stånd efter OS-turneringen 1948. Typiskt nog segrade Sverige sedan man med ett robust spel decimerat det danska laget (genom att reglerna ännu inte tillät att skadade spelare ersattes). Svenskarna förnekade att man agerat speciellt hårt. En spelare yttrade att danskarna borde träna upp sina svaga vrister bättre, så att de inte behövde linka omkring på planen.

Återigen framkom tydligt att manlighetsidealen faktiskt skilde sig åt i svensk och dansk fotboll. Den flera decennier lån- 
ga debatten om de hårdföra svenska »danskdödarna« belyser meningsskiljaktigheterna. Svensk fotboll, med dess långvariga prägling från arbetarklassen, hade en annan kraftfullhet och tolererade ett större mått av hårdhet. De svenska landslagsspelarna var kraftigare byggda och det påpekades att Sverige bättre exploaterat det goda människomaterialet i landsbygden. Mot svenskt gravallvar ställdes danskarnas mer nöjesinriktade inställning. Den danska fotbollen var alltjämt huvudstadsbaserad och hade djupare rötter $\mathrm{i}$ gentlemannakulturen och satte överlag en långt större ära i listen, elegansen och intelligensen.

Dessa föreställningar om skilda spelstilar kom att leva kvar. Trots detta började landskampen mellan Sverige och Danmark efterhand att tappa i intresse. Situationen var den att Sverige under 60-talet oftast vann, varför publiksiffrorna i Sverige dalade kraftigt. För att råda bot på detta flyttade man matcherna från Stockholm till Göteborg och framförallt Malmö. Framemot 80 -talet hade den publika magin runt matchen också försvunnit i Köpenhamn. Fotbollens värld hade blivit så global att en match mot grannlandet inte längre betecknade någon idrottslig höjdpunkt. Likafullt måste sägas att många av de föreställningar som än idag finns om skillnaderna mellan svensk och dansk kultur och mentalitet - och som snarast accentuerats genom Öresundsbrons tillkomst - känns igen från landskampstraditionens långa historia. Vissa stereotyper om de olika länderna kommer säkerligen att användas igen när Sverige och Danmark möts i viktiga kvalmatcher till EM-slutspelet 2008.

\section{Noter}

1. Artikeln bygger på en ombearbetning av vissa avsnitt i Torbjörn Anderssons Kung Fotboll (2002). För mer detaljerade referenser se sid 268292, 447-464 och 576-592.

2. Ehn B, Frykman J \& Löfgren O. (1993), pp. 5053.

3. Linde-Laursen A. (1995), p. 106.

4. Nordiskt Idrottslif, nr. 33 1915, p. 271.

5. Idrottsbladet, nr. 32 1915, p. 188.

6. Idrottsbladet, nr. 97 1920, p. 607.

7. Nordiskt Idrottslif, nr. 29 1916, p. 232.

8. Idrottsbladet, nr. 34 1917, p. 134.

9. Billig M. (1997), pp. 1-12 och 119-125.

10. Bringéus N.-A. (1976), pp. 197-198.

11. Nordiskt Idrottslif, nr. 63 1917, p. 497.

12. Nordiskt Idrottslif, nr. 64 1918, p. 506.

13. Nordiskt Idrottslif, nr. 44 1915, pp. 357-358.

14. Nordiskt Idrottslif, nr. 21 1917, p. 164.

15. Nordiskt Idrottslif, nr. 65 1918, p. 509.

16. Nordiskt Idrottslif, nr. 65 1918, p. 512.

17. Nordiskt Idrottslif, nr. 47 1919, p. 370.

18. Nordiskt Idrottslif, nr. 47 1919, p. 372.

19. Nordiskt Idrottslif, nr. 59 1920, p. 471.

20. Idrottsbladet, nr. 117 1922, p. 2.

21. Idrottsbladet, nr. 118 1922, p. 3.

22. Idrottsbladet, nr. 77 1929, p. 7.

23. Förbindelserna mellan England och Skottland kan rimligtvis inte ha ingått $\mathrm{i}$ denna jämförelse som gjordes i Idrottsbladet, nr. 70 1936, p. 8.

24. Idrottsbladet, nr. 59 1921, p. 408.

25. Idrottsbladet, nr. 2 1920, s 9.

26. Idrottsbladet, nr. 141 1933, s 8.

27. Idrottsbladet, nr. 75 1927, s 6.

28. Idrottsbladet, nr. 76 1938, s 2 och nr. 79 1938, s 8.

29. Idrottsbladet, nr. 74 1939, s 9.

30. Idrottsbladet, nr. 116 1942, s 7.

31. Idrottsbladet, nr. 116 1947, s 8. 


\section{Litteratur}

Andersson T. Kung Fotboll. Den svenska fotbollens kulturhistoria från 1800-talets slut till 1950 (Stockholm, 2002).

Billig M. Banal Nationalism (London, 1997).

Bringéus N.-A., Årets festseder (Stockholm, 1976).

Ehn B, Frykman J \& Löfgren O. Försvenskningen av Sverige. Det nationellas förvandlingar, (Stockholm, 1993).
Idrottsbladet.

Linde-Laursen A. Det nationales natur. Studier $i$ dansk-svenske relationer (Lund, 1995).

Nordiskt Idrottslif.

Sundbärg G. Det svenska folklynnet (Stockholm, 1911). 
